\title{
ANALISIS KEMAMPUAN PEMAHAMAN SISWA DALAM MENYELESAIKAN SOAL CERITA PROGRAM LINIER DI KELAS XI
}

\section{(DETERMINE THE ABILITY OF STUDENTST OUNDERSTAND THE PROBLEM SOLVING LINEAR PROGRAM IN THE 1OTH GRADE OF SMA)}

\author{
Agustina $^{1}$, Syaifudin $^{2}$, Agus Supriadi ${ }^{3}$ \\ ${ }^{1}$ Universitas Muhammadiyah Palembang, agustinatinatina414@gmail.com \\ ${ }^{2}$ Universitas Muhammadiyah Palembang, syaifuddinump@gmail.com \\ ${ }^{3}$ Universitas Muhammadiyah Palembang, sirsupriadi1981@gmail.com
}

\begin{abstract}
Abstrak
Adapun tujuan dari penelitian ini adalah untuk mengetahui kemampuan pemahaman siswa dalam menyelesaikan soal cerita program linier SMA Negeri 10 Palembang kelas XI. Jenis penelitian ini adalah penelitian deskriptif dengan pendekatan kualitatif, populasi dalam penelitian ini adalah seluruh siswa kelas XI SMA Negeri 10 Palembang pada tahun ajaran 2016/2017 yang berjumlah 8 kelas MIA dan 6 kelas IIS. Sampel dalam penelitian ini adalah $25 \%$ dari seluruh siswa kelas XI SMA Negeri 10 Palembang pada tahun ajaran 2016/2017 yang dipilih dengan teknik non probability sampling dengan jenis sampling purposive, adapun sampel dalam penelitian ini yaitu kelas XI MIA 4 yang berjumlah 40 siswa, XI MIA 5 yang berjumlah 41 siswa, dan XI MIA 6 yang berjumlah 41 siswa. Teknik pengumpulan data yang digunakan dalam penelitian ini adalah peneliti mengambil hasil ulangan harian siswa kepada guru mata pelajaran matematika. Berdasarkan hasil analisis data yang telah dilakukan diperoleh rata-rata kemampuan pemahaman siswa dalam menyelesaikan soal cerita program linier yaitu sebesar 45,4\%. Jadi kemampuan pemahaman siswa dalam menyelesaikan soal cerita program linier kelas XI terhadap 3 jenis kemampuan pemahaman (konsep, prinsip, operasi) dapat dikategorikan cukup.
\end{abstract}

Kata Kunci: Kemampuan Siswa, Soal Cerita, Model Matematika, Program Linier

\begin{abstract}
The purpose of this study is to determine the ability of studentst ounderstand the problem solving linear program in the 10th grade of SMA Negeri Palembang Palembang. This type of research is a descriptive study with a qualitative approach, the population in this study were all students of class XI Palembang State High School 10 in the 2016/2017 school year which numbered 8 MIA classes and 6 IIS classes. The sample in this study was $25 \%$ of all students of class XI Palembang 10 HighSchool in the 2016/2017 school year selected by non probability sampling techniques with a type of purposive sampling, while the samples in this study were class XI MIA 4, amounting to 40 students, XI MIA 5, amounting to 41 students, and XI MIA 6 , which amounted to 41 students. The data collection technique used in this study was that there search ertook the students' daily test results to the mathematics teacher. Based on there sult soft he data analysis that has been
\end{abstract}


done, it is obtained that the average ability of students to understand linear program story problems is $45.4 \%$. So the ability of students to understand the linear problem in class XI program on 3 types of comprehensi on skills (concepts, principles, operations) can be categorized sufficiently.

Keywords: Student Ability, Story Problems, Mathematical Models, Linear Programs.

\section{PENDAHULUAN}

Pendidikan merupakan suatu kebutuhan bagi seorang manusia untuk menghadapi perkembangan ilmu pengetahuan dan teknologi yang semakin modern di era globalisasi saat ini. Ilmu pengetahuan dan teknologi sangat diperlukan agar seseorang dapat mengembangkan ide-ide yang lebih cerdas dan kreatif sesuai dengan bakatnya masing-masing. Menurut Ki Hajar Dewantara (dalam Seri: 2007), pendidikan adalah menuntun segala kekuatan kodrat yang ada pada anak-anak, agar mereka sebagai manusia dan sebagai anggota masyarakat mendapatkan keselamatan dan kebahagiaan yang setinggi-tingginya.

Matematika adalah mata pelajaran yang sudah ada di setiap jenjang pendidikan mulai dari pendidikan usia dini hingga perguruan tinggi yang membutuhkan pemahaman dan penguasaan konsep agar dapat mengembangkan kemampuan matematis siswa.

Dalam proses belajar matematika yang dibutuhkan tidak hanya sekedar menghafal, tetapi juga diperlukan pemahaman mengenai apa yang dipelajari. Dalam keberhasilan belajar matematika, diperlukan kemampuan memahami konsep-konsep, prinsip-prinsip, dan operasi dasar dengan tidak hanya menghafal tetapi juga menekankan aspek pemahaman konsep, prinsip dan operasi matematika tersebut sebagai tolak ukur keberhasilan dalam mempelajari matematika.

Program linier merupakan salah satu materi pokok dalam mata pelajaran matematika yang diajarkan pada siswa di jenjang sekolah menengah atas (SMA). Program linier merupakan materi yang memerlukan penyelesaian dengan tingkat ketelitian yang cukup tinggi terutama dalam menyelesaikan soal cerita program linier.

Program linear adalah materi matematika yang dipelajari di kelas XI matematika wajib bagi sekolah yang sudah menggunakan kurikulum 2013. Sebelum siswa mempelajari materi program linear, siswa terlebih dahulu memahami materi sistem pertidaksamaan linear dua variabel (SPLDV) yang dipelajari di kelas X. Berdasarkan pengalaman selama PPL dan nilai tugas siswa yang diperoleh dari guru matematika di SMA Negeri 10 Palembang peneliti melihat sebagian besar dari siswa tersebut melakukan kesalahan dalam menyelesaikan soal yang berbentuk cerita dan kemampuan siswa dalam menyelesaikan soal cerita program linier masih rendah.

Berdasarkan uraian di atas, maka peneliti tertarik untuk mengadakan penelitian dengan judul "Analisis Kemampuan Pemahaman Siswa Dalam Menyelesaikan Soal Cerita Program Linier SMA Negeri 10 Palembang Kelas XI”. 


\section{METODE PENELITIAN}

Pendekatan yang digunakan dalam penelitian ini adalah pendekatan kualitatif dengan jenis penelitian deskriptif. Menurut Sanjaya (2013: 59), penelitian deskriptif (descriptive research) adalah penelitian yang dilakukan untuk menggambarkan atau menjelaskan secara sistematis, factual dan akurat mengenai fakta dan sifat populasi tertentu.

Dalam penelitian deskriptif, peneliti hendak menggambarkan suatu gejala (fenomena), atau sifat tertentu tidak untuk mencari atau menerangkan keterkaitan antar variabel dan hanya melukiskan atau menggambarkan apa adanya, Stephen (Sanjaya, 2013: 59). Jadi dalam penelitian ini, peneliti hanya ingin mengetahui kemampuan yang dimiliki siswa dalam menyelesaikan soal cerita program linier di SMA Negeri 10 Palembang kelas XI.

\section{HASIL DAN PEMBAHASAN}

Penelitian ini bertujuan untuk menganalisis kemampuan siswa dalam mengubah bentuk soal cerita menjadi model matematika di SMA Negeri 10 Palembang kelas XI, dengan menganalisis 3 kategori kemampuan yaitu kemampuan siswa memahami konsep, kemampuan siswa memahami prinsip matematika, dan kemampuan siswa memahami operasi matematika.

Dalam penelitian ini, peneliti hanya menganalisis hasil ulangan harian siswa. Dimana soal ulangan harian siswa tersebut berjumlah 4 soal program linier yang terkait dengan soal cerita. Soal-soal tersebut dikelompokkan dalam 3 jenis kemampuan yaitu kemampuan pemahaman konsep, kemampuan pemahaman prinsip matematika, dan kemampuan pemahaman operasi.

Analisis data dalam penelitian ini dilakukan untuk melihat kemampuan siswa dalam mengubah bentuk soal cerita menjadi model matematika yang dikelompokkan dalam 3 jenis kemampuan yaitu pemahaman konsep, pemahaman prinsip, dan pemahaman operasi matematika.

Dari hasil ulangan harian siswa diperoleh banyak skor yang muncul untuk tiap-tiap aspek kemampuan. Adapun banyak tiap skor yang muncul untuk masingmasing soal adalah sebagai berikut:

1. Kemampuan Pemahaman Konsep, Prinsip, Operasi

Kemampuan siswa dalam menyelesaikan soal cerita yang digolongkan pada 3 jenis kemampuan terdiri dari 4 soal.

\section{Nomor 1}

Sebuah toko bunga menjual 2 macam rangkaian bunga. Rangkaian I memerlukan 10 tangkai bunga mawar dan 15 tangkai bunga anyelir. Rangkaian II memerlukan 20 tangkai bunga mawar dan 5 tangkai bunga anyelir. Persediaan bunga mawar dan bunga anyelir masing-masing 200 tangkai dan 100 tangkai. Jika rangkaian I dijual seharga Rp200.000,00 dan rangkaian II dijual seharga Rp100.000,00 per rangkaian, maka penghasilan maksimum yang dapat diperoleh adalah...

Kemampuan pemahaman konsep siswa pada soal nomor 1 diperoleh $62 \%$ siswa menjawab kurang lengkap dan tidak benar dan 37\% siswa menjawab kurang lengkap tetapi benar. Kemampuan pemahaman prinsip siswa pada nomor 1 diperoleh $36 \%$ siswa tidak menjawab sama sekali, 24\% siswa menjawab kurang lengkap dan tidak benar, $0,8 \%$ siswa yang menjawab lengkap tetapi tidak benar, $33 \%$ siswa menjawab kurang lengkap tetapi benar, dan 5\% siswa menjawab 
lengkap dan benar. Kemampuan pemahaman operasi siswa pada nomor 1 diperoleh $0,8 \%$ siswa tidak menjawab sama sekali, $45 \%$ siswa menjawab kurang lengkap dan tidak benar, $12,9 \%$ siswa yang menjawab lengkap tetapi tidak benar, 19,8\% siswa menjawab kurang lengkap tetapi benar, dan 20,6\% siswa menjawab lengkap dan benar.

\section{Nomor 2}

Anak usia balita dianjurkan dokter untuk mengonsumsi kalsium dan zat besi sedikitnya 60 gr dan 30 gr. Sebuah kapsul mengandung 5 gr kalsium dan 2 gr zat besi, sedangkan sebuah tablet mengandung 2 gr kalsium dan 2 gr zat besi. Jika harga sebuah kapsul Rp1.000,00 dan harga sebuah tablet Rp800,00, maka biaya minimum yang harus dikeluarkan untuk memenuhi kebutuhan anak balita tersebut adalah...

Kemampuan pemahaman konsep siswa pada soal nomor 2 diperoleh $13,7 \%$ siswa tidak menjawab sama sekali, 56,8\% siswa menjawab kurang lengkap dan tidak benar, $16 \%$ siswa menjawab kurang lengkap tetapi benar dan 12,9\% siswa menjawab lengkap dan benar. Kemampuan pemahaman prinsip siswa pada soal nomor 2 diperoleh 12,9\% siswa tidak menjawab sama sekali, 31,8\% siswa menjawab kurang lengkap dan tidak benar, 2,5\% siswa yang menjawab lengkap tetapi tidak benar, $49 \%$ siswa menjawab kurang lengkap tetapi benar, dan 3\% siswa menjawab lengkap dan benar. Kemampuan pemahaman operasi siswa pada soal nomor 2 diperoleh $12 \%$ siswa tidak menjawab sama sekali, $25 \%$ siswa menjawab kurang lengkap dan tidak benar, 27,5\% siswa yang menjawab lengkap tetapi tidak benar, $13,7 \%$ siswa menjawab kurang lengkap tetapi benar, dan 21,5\% siswa menjawab lengkap dan benar.

Jika dirata-ratakan maka kemampuan pemahaman siswa dalam menyelesaikan soal cerita program linier sebesar 45,4\%, ini berarti kemampuan siswa tersebut dikategorikan cukup.

Akan dibahas temuan-temuan dari analisis hasil ulangan harian siswa berdasarkan soal-soal cerita yang berhubungan dengan materi program linier. Dimana soal ulangan harian siswa tersebut berjumlah 4 soal program linier yang terkait dengan soal cerita. Soal-soal tersebut dikelompokkan dalam 3 jenis aspek kemampuan yaitu kemampuan pemahaman konsep, kemampuan pemahaman prinsip, dan kemampuan pemahaman operasi matematika.

Hasil analisis jawaban siswa untuk masing-masing aspek kemampuan diperoleh kemampuan pemahaman siswa untuk indikator konsep diperoleh persentase sebesar 29\%. Kemampuan pemahaman siswa untuk indikator prinsip diperoleh persentase sebesar 53,8\%. Sedangkan kemampuan pemahaman siswa untuk indikator operasi diperoleh persentase sebesar 53,6\%.

Jika dirata-ratakan kemampuan pemahaman siswa dalam menyelesaikan soal cerita program linier diperoleh persentase sebesar 45,4\%. Jadi kemampuan pemahaman siswa dalam menyelesaikan soal cerita program linier kelas XI terhadap 3 jenis kemampuan pemahaman (konsep, prinsip, operasi) dapat dikategorikan cukup.

Bila ditinjau dari jawaban siswa dapat dilihat tiap-tiap aspek kemampuan siswa dalam menyelesaikan soal cerita adalah sebagai berikut: 


\section{1) Kemampuan Pemahaman Konsep Siswa dalam Menyelesaikan Soal Cerita Program Linier}

Kemampuan siswa dalam memahami konsep yang berhubungan dengan soal cerita program linier merupakan kemampuan siswa dalam memahami makna soal, lalu mampu dalam menerjemahkan soal kedalam model matematika, kemudian menggunakan konsep-konsep variabel yang digunakan untuk membuat model matematika. Dari hasil jawaban siswa diperoleh 5\% dari keseluruhan yang tidak menjawab sama sekali, 65,5\% dari keseluruhan yang menjawab kurang lengkap dan tidak benar, $0,2 \%$ dari keseluruhan yang menjawab lengkap tetapi tidak benar, 25,8\% dari keseluruhan yang menjawab kurang lengkap tetapi benar, dan 3\% dari keseluruhan yang menjawab lengkap dan benar, dan dari hasil yang diperoleh ternyata persentase siswa yang jawabannya tidak benar sangat tinggi. Hal ini terjadi dikarenakan siswa belum mampu memahami makna soal dengan baik, kurangnya pemahaman konsep terkait soal cerita program linier, dan kurangnya pemahaman mengenai lambang atau simbol-simbol dalam matematika, berikut beragam contoh jawaban siswa terhadap pemahaman konsep.

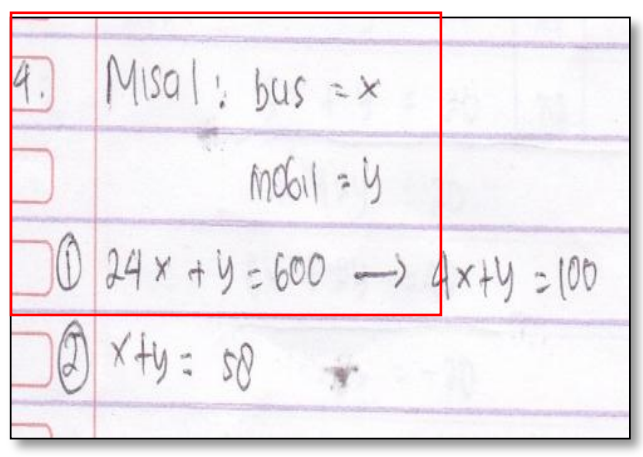

(a)

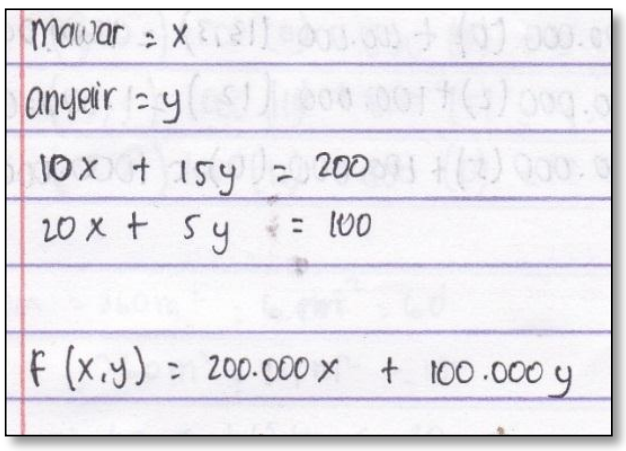

(b)

Gambar 1. Contoh Jawaban Siswa yang Kurang Lengkap

Tidak benar karena pada jawaban tersebut sudah sangat jelas bahwa siswa salah dalam melakukan permisalan, dan tidak benar dalam menuliskan pertidaksamaan. Seharusnya jawaban yang benar itu, siswa memisalkan rangkaian I dan rangkaian II sebagai $\mathrm{x}$ dan y atau variabel lain, kemudian membuat fungsi kendala dan fungsi tujuan. Sedangkan pada Gambar 1 (b) siswa salah dalam menuliskan pertidaksamaan seperti $24 x+y=600$ dan $x+y=58$ karena jawaban seharusnya adalah $24 x+6 y \leq 600$ dan $x+y \leq 58$, siswa juga tidak menuliskan fungsi tujuan, kemudian siswa tidak menuliskan $x \geq 0$ dan $y \geq 0$. 


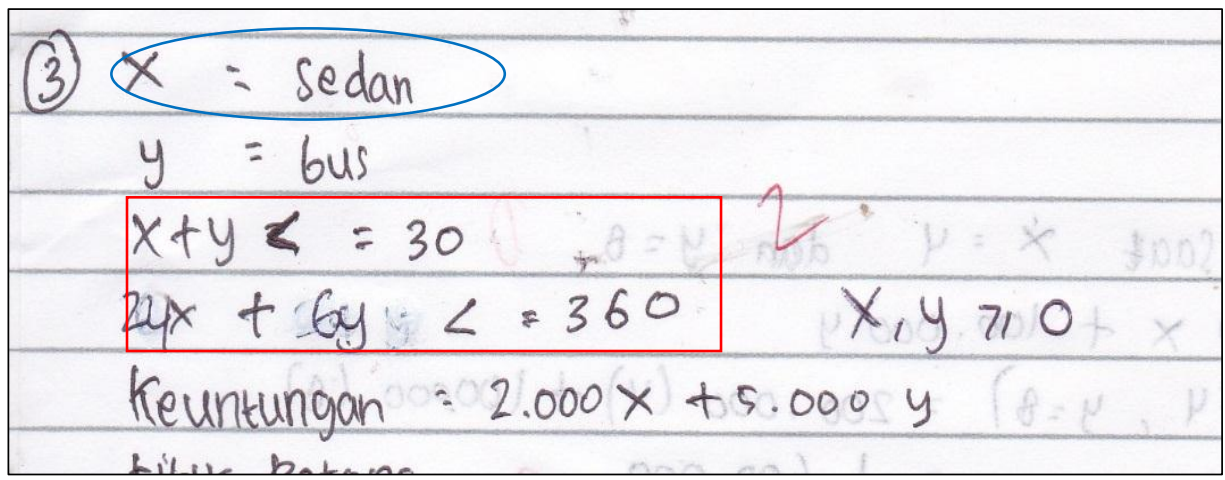

Gambar 2. Jawaban Siswa Lengkap, tetapi Tidak Benar pada Pemahaman Konsep

Benar, karena pada jawaban tersebut siswa memisalkan $\mathrm{x}$ sebagai sedan sedangkan didalam soal tidak terdapat sedan, kemudian salah dalam menuliskan fungsi kendala.

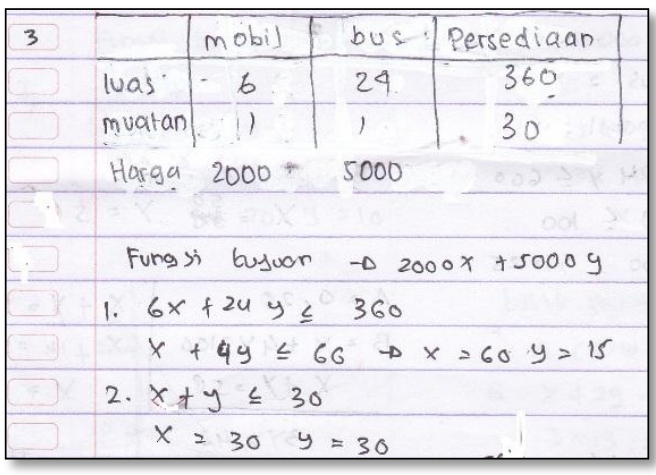

(a)

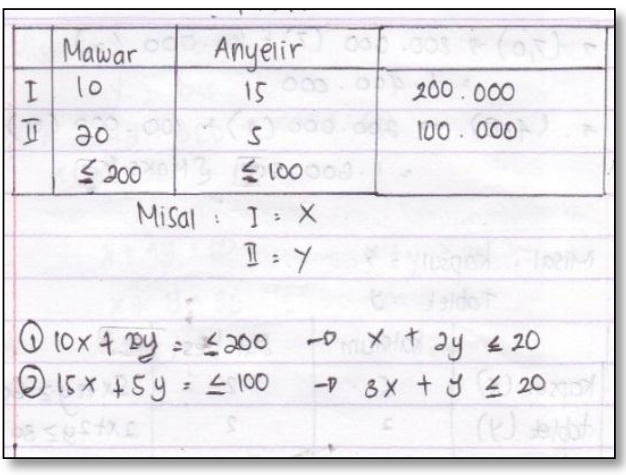

(b)

Gambar 3. Jawaban Siswa Kurang Lengkap Tetapi Benar pada Pemahaman Konsep

Gambar 3 (a) merupakan contoh jawaban siswa yang kurang lengkap tetapi benar, karena jawaban siswa pada nomor 1 siswa tidak menuliskan fungsi tujuan dari model matematikanya dan tidak menuliskan $x \geq 0$ dan $y \geq 0$. Sedangkan Gambar 3 (b) siswa tidak menuliskan permisalan variabel dan tidak menuliskan $x \geq 0$ dan $y \geq 0$. 


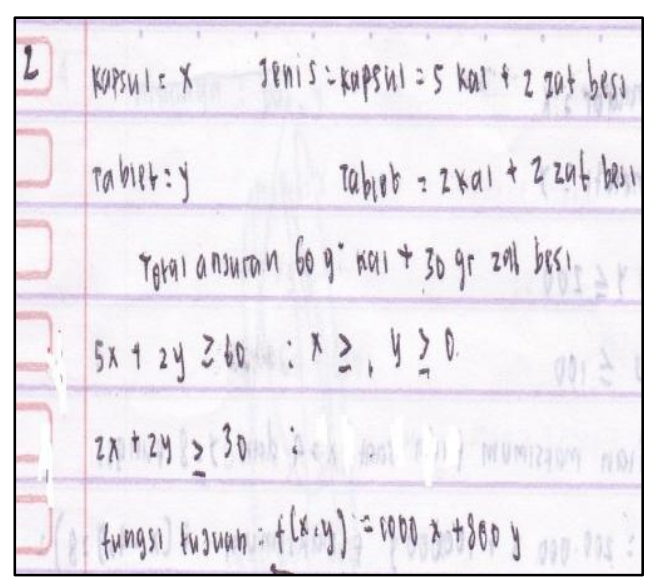

(a)

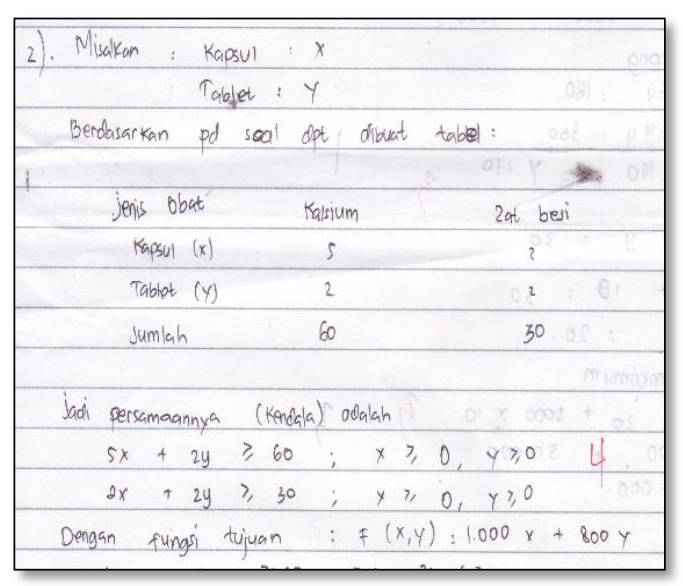

(b)

Gambar 4. Jawaban Siswa Lengkap dan Benar pada Pemahaman Konsep

Gambar 4 (a) dan (b)merupakan contoh jawaban siswa yang lengkap dan benar, karena pada jawaban tersebut siswa menuliskan permisalan variabel denganbenar, kemudian menuliskan pertidaksamaan dengan benar, menuliskan fungsi tujuan dengan benar dan siswa juga menuliskan $x \geq 0$ dan $y \geq 0$.

Dari hasil jawaban siswa dapat disimpulkan bahwa kemampuan pemahaman siswa pada konsep matematika masih tergolong rendah, karenasiswa belum mampu memahami makna soal dengan baik sehingga melakukan kesalahan pada saat memisalkan variabel dan membuat pertidaksamaan, dan siswa terkadang melupakan bahwa selain benar, jawaban yang dibuat juga harus lengkap.

\section{2) Kemampuan Pemahaman Prinsip Siswa dalam Menyelesaikan Soal Cerita Program Linier}

Kemampuan siswa dalam memahami prinsip yang berhubungan dengan soal cerita materi program linier merupakan kemampuan siswa dalam mengaitkan beberapa fakta atau beberapa konsep. Dari hasil jawaban siswa 13,5\% dari keseluruhan yang tidak menjawab sama sekali, 31\% dari keseluruhan yang menjawab kurang lengkap dan tidak benar, $1 \%$ dari keseluruhan yang menjawab lengkap tetapi tidak benar, 50\% dari keseluruhan yang menjawab kurang lengkap tetapi benar, dan 3,8\% dari keseluruhan yang menjawab lengkap dan benar dan dari hasil yang diperoleh ternyata sebagian besar yang menjawab dengan benar hanya saja jawaban yang dibuatnya tidak lengkap. Meskipun begitu, masih banyak yang tidak menjawab sama sekali dan persentase cukup tinggi juga untuk yang menjawab tidak lengkap dan tidak benar. Hal ini terjadi dikarenakan siswa masih bingung mengenai metode apa yang harus mereka gunakan untuk menyelesaikan soal. Berikut contoh kesalahan prinsip yang dilakukan siswa: 


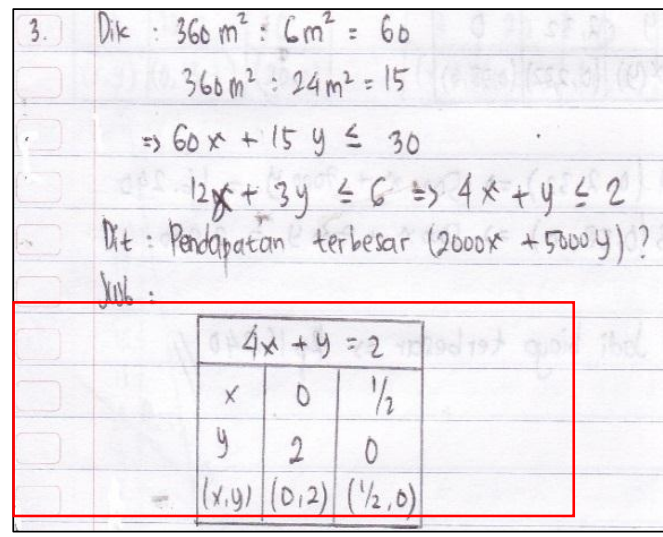

(a)

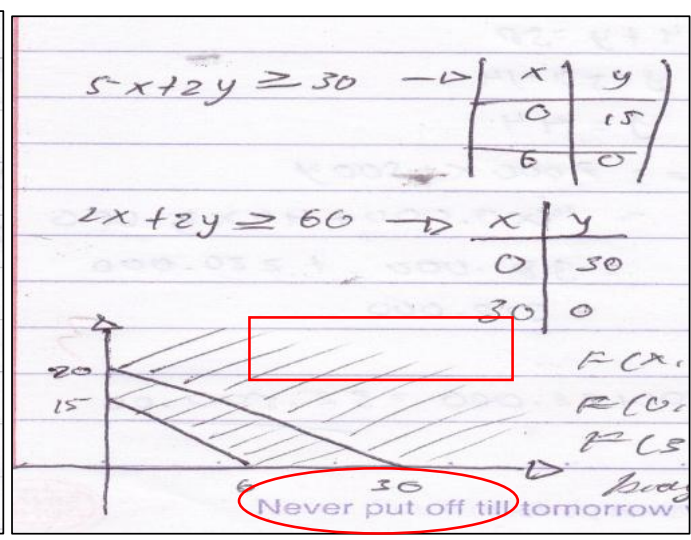

(b)

Gambar 5. Jawaban Siswa Kurang Lengkap dan Tidak Benar pada Pemahaman Prinsip

Gambar 5 (a) merupakan contoh jawaban siswa yang kurang lengkap dan tidak benar, karena jawaban siswa pada nomor 2 siswa tidak mencari titik potong dan salah dalam menggambar grafik. Sedangkan Gambar 5 (b) siswa sudah salah membuat pertidaksamaan sehingga pada saat siswa mencari titik-titik koordinat juga salah, siswa tidak mencari titik potong dan tidak menggambar grafik. Seharusnya jawaban yang benar adalah siswa menentukan titik-titik koordinat terlebih dahulu, kemudian menggunakan metode eliminasi subtitusi untuk menentukan titik potong, setelah itu menggambar grafik sesuai dengan titik-titik koordinat, dan menentukan himpunan penyelesaiannya.

2. $\begin{array}{rr}5 x+2 y \leq 60+m+g \text { sb } x, y=0 & m+g \text { sb } y, x=0 \\ 5 x=60 & 2 y=60 \\ x=12 & y=30 \\ 2 x+2 y \leq 30 j & m+g \text { sb } y, x=0 \\ m+g \text { sb } x, y=0 & 2 y=30 \\ 2 x=30-x=15 & y=15 \\ m+g \text { sb } y, x=0 & \\ 2 g=30 & \\ y=15 & \end{array}$

(a)

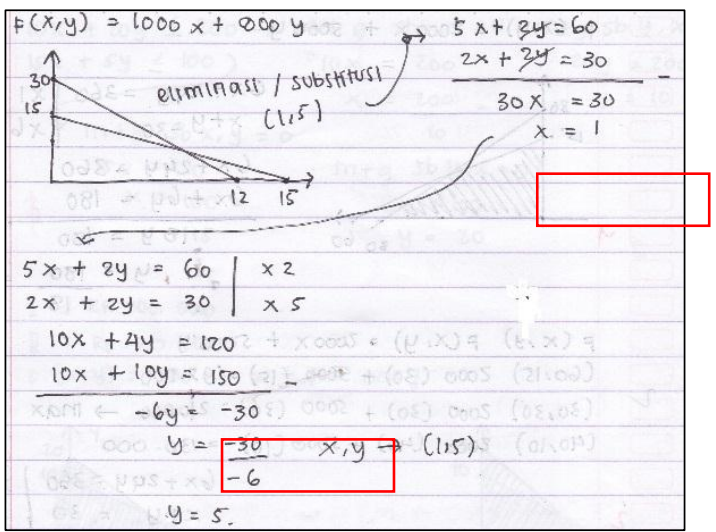

(b)

Gambar 6. Jawaban Siswa Lengkap tetapi Tidak Benar pada Pemahaman Prinsip

Gambar 6 (a) merupakan contoh jawaban siswa yang lengkap tetapi tidak benar, karena jawaban siswa pada nomor 1 siswa sudah keliru dalam membuat model matematika otomatis dalam menentukan titik-titik koordinat, menentukan titik potong, dan menggambar grafik juga salah. Sedangkan Gambar 6 (b) siswa salah dalam menentukan titik potong, dalam jawabannya siswa mendapatkan hasil $\mathrm{x}=1$ sedangkan jawaban yang seharusnya adalah $\mathrm{x}=10$. Meskipun jawaban yang 
dituliskan siswa lengkap tetapi apa yang dituliskan tidak sesuai dengan yang diinginkan.

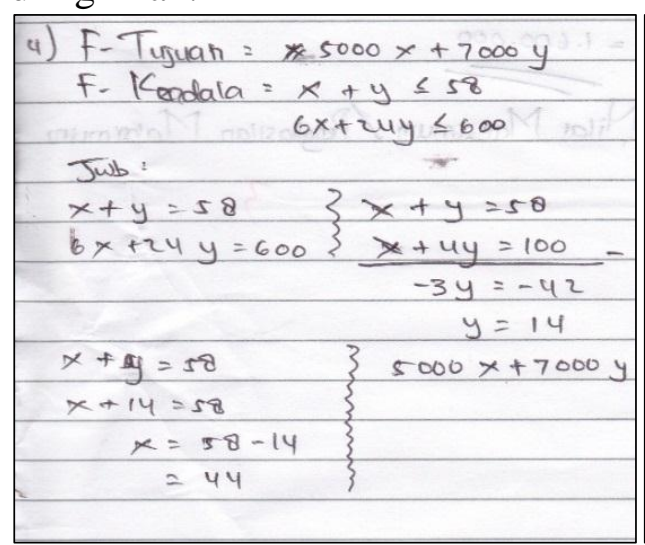

(a)

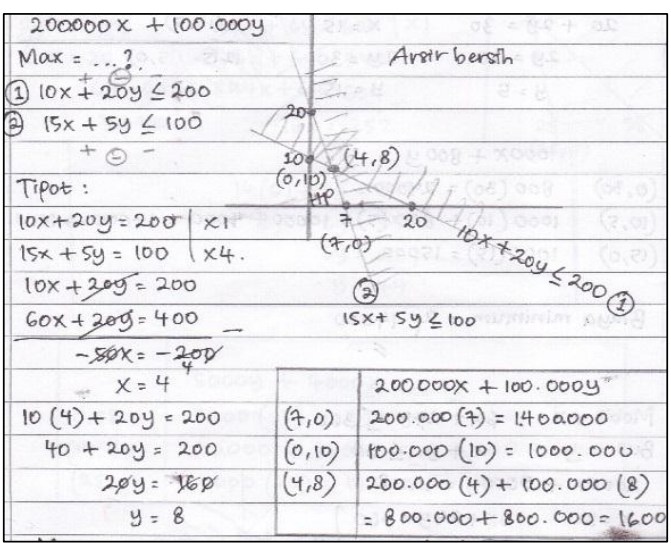

(b)

Gambar 7. Jawaban Siswa Kurang Lengkap tetapi Benar pada Pemahaman Prinsip

Gambar 7 (a) merupakan contoh jawaban siswa yang kurang lengkap tetapi benar, karena jawaban siswa pada nomor 4 siswa hanya menentukan titik potong dengan menggunakan metode eliminasi subtitusi, tetapi tidak menentukan titik-titik koordinat serta tidak menggambar grafiknya. Dalam program linier grafik sangatlah penting untuk menentukan titik-titik yang akan yang diuji. Sedangkan Gambar 5.7 (b) siswa tidak menentukan titik-titik koordinat, siswa hanya menentukan titik potong dengan menggunakan metode eliminasi subtitusi, kemudian siswa menggambar grafik. Seharusnya jawaban yang benar dan lengkap adalah siswa menentukan titik-titik koordinat terlebih dahulu, kemudian menggunakan metode eliminasi subtitusi untuk menentukan titik potong, setelah itu menggambar grafik sesuai dengan titik-titik koordinat, dan menentukan himpunan penyelesaiannya.

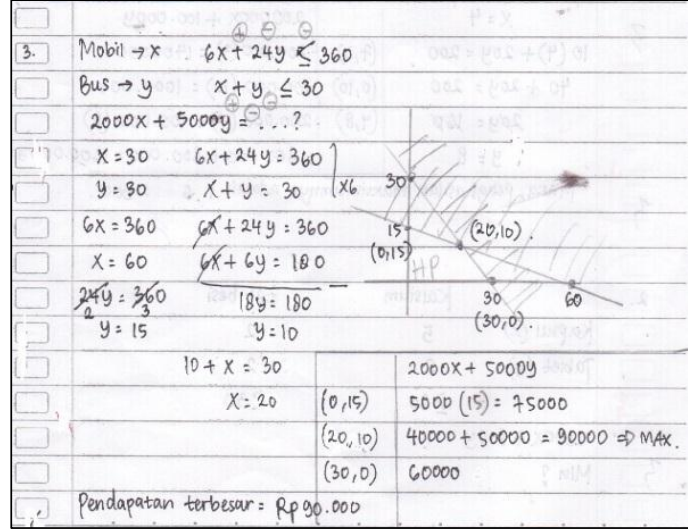

(a)

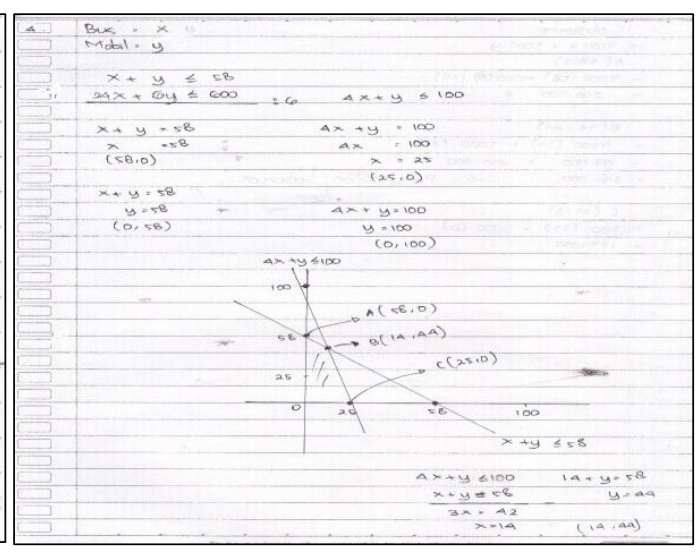

(b)

Gambar 8. Jawaban Lengkap dan Benar pada Pemahaman Prinsip 
Gambar 8 (a) dan (b) merupakan contoh jawaban siswa yang lengkap dan benar, karena siswa menentukan titik-titik koordinat dengan benar, menentukan titik potong dengan menggunakan metode eliminasi subtitusi juga benar, dan siswa menggambar grafik dengan tepat.

Dari hasil jawaban siswa dapat disimpulkan bahwa kemampuan pemahaman siswa pada prinsip matematika terkait soal cerita program linier masih rendah, dikarenakan siswa masih sering keliru dalam membuat model matematika sehingga berakibat fatal pada jawaban siswa, dan masih sering keliru mengenai metode dan langkah-langkah penyelesaiannya.

\section{3) Kemampuan Pemahaman Operasi Siswa dalam Menyelesaikan Soal Cerita Program Linier}

Kemampuan siswa dalam memahami operasi yang terkait dengan soal cerita materi program linier merupakan kemampuan siswa dalam pengerjaan hitung, pengerjaan aljabar, dan pengerjaan matematika yang lain. Dari jawaban siswa diperoleh 7\% dari keseluruhan yang tidak menjawab sama sekali, 27\% dari keseluruhan yang menjawab kurang lengkap dan tidak benar, $12 \%$ dari keseluruhan yang menjawab lengkap tetapi tidak benar, 38\% dari keseluruhan yang menjawab kurang lengkap tetapi benar, dan $15,5 \%$ siswa menjawab lengkap dan benar. Hal ini terjadi dikarenakan siswa masih sering keliru dalam menghitung dan tidak melanjutkan prosedur penyelesaian, serta terkadang siswa lupa menuliskan kesimpulan atau jawaban akhir dari soal. Berikut contoh siswa melakukan kekeliruan dalam operasi:

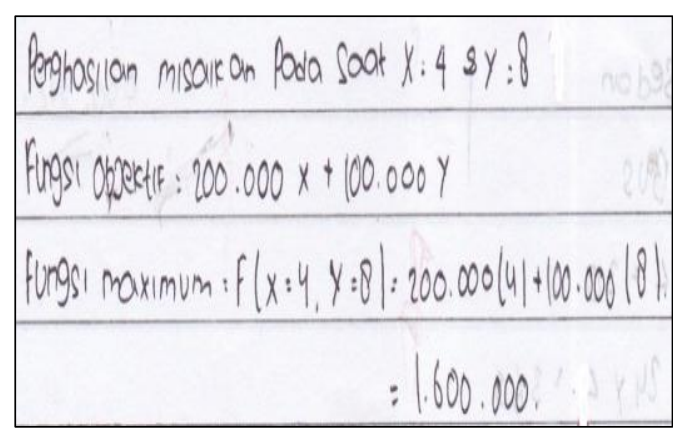

(a)

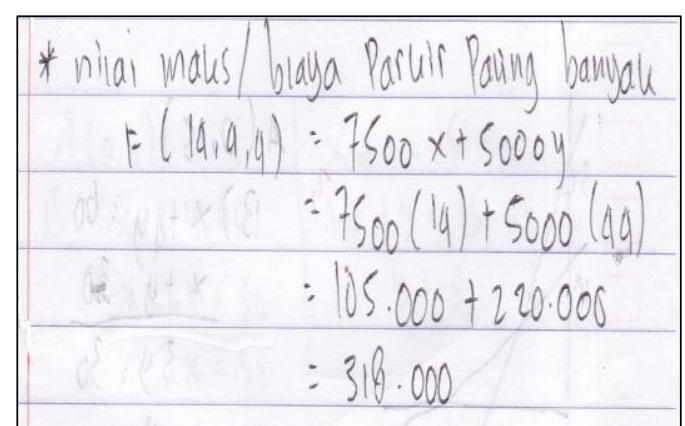

(b)

Gambar 9. Jawaban Kurang Lengkap dan Tidak Benar pada Pemahaman Operasi

Gambar 9 (a) merupakan contoh jawaban siswa yang kurang lengkap dan tidak benar, karena jawaban siswa tersebut hanya menguji satu titik, meskipun titik yang diuji itu benar tetapi siswa tidak menjelaskan cara memperoleh titik-titik tersebut sehingga tidak bisa dibenarkan jawabannya. Sedangkan Gambar 9 (b) siswa hanya menguji satu titik yaitu $(14,44)$ titik yang dipilih siswa sudah benar tetapi siswa salah dalam menuliskan fungsi tujuan, fungsi tujuan yang benar adalah $7000 x+5000 y$ tetapi siswa menuliskan $7500 x+5000 y$, dan siswa juga salah dalam menjumlahkan. Jawaban seharusnya adalah siswa memilih beberapa titik yang akan diuji, setelah itu barulah menentukan jawaban akhir dari soal. 


\begin{tabular}{|c|c|}
\hline $\begin{aligned} \rightarrow & 1000(x)+800(y) \\
& A(0,15)\end{aligned}$ & $B(12,5)$ \\
\hline$\varphi \pm 1000(0)+800(15)$ & $L=1000+2300$ \\
\hline$=12.000$ & $=14000$ \\
\hline$(0=0,0005$ & Jadi. Biaya misimu \\
\hline$C(12,0)$ & a dalah $R_{p} 12.000$ \\
\hline$L=1000(12)+800(0)$ & \\
\hline$=12$ & \\
\hline
\end{tabular}

(a)

$A=(0,13.3)=200000\left(0^{\circ}\right)+100000(13.3)=1.330 .000$
$B=(2,12)=200000(2)+100000(12)=1.600 .000$ (maks)
$C=(5,0)=200000(5)+100000(0)=1.000 .000$

(b)

Gambar 10. Jawaban Lengkap Tetapi Tidak Benar pada Pemahaman Operasi

Gambar 10 (a) dan (b) merupakan contoh jawaban siswa yang lengkap tetapi tidak benar, karena pada jawaban siswa tersebut sudah menguji beberapa titik, hanya saja titik-titik yang diuji kurang tepat sehingga berdampak pada hasil akhir. Jawaban seharusnya adalah setelah siswa memilih beberapa titik yang berada dalam himpunan penyelesaian, setelah itu barulah menentukan jawaban akhir atau kesimpulan. Untuk lebih jelas akan ditunjukkan grafiknya terlebih dahulu:

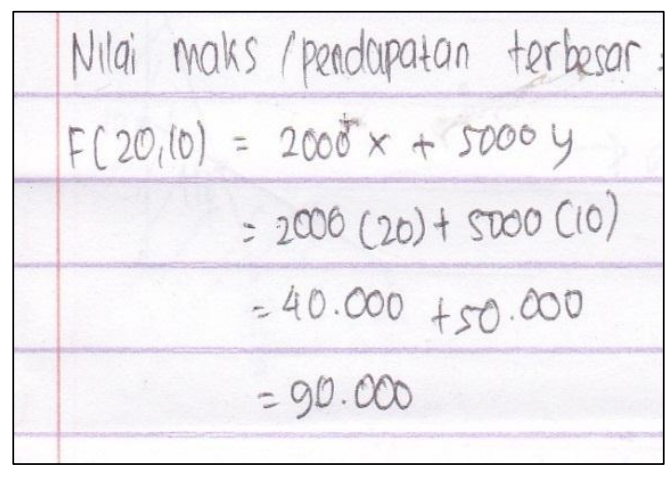

(a)

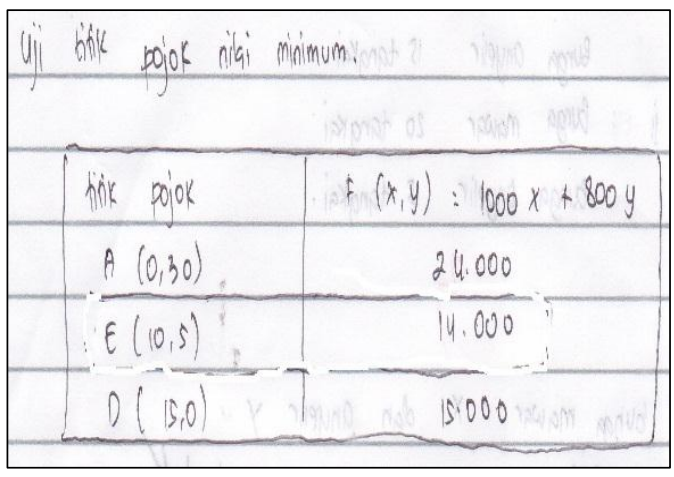

(b)

Gambar 11. Jawaban Kurang Lengkap Tetapi Benar pada Pemahaman Operasi

Gambar 11 (a) merupakan contoh jawaban siswa yang kurang lengkap tetapi benar, karena jawaban siswa hanya menguji satu titik saja yaitu tepat berada di titik potong, sedangkan pada Gambar 11 (b) siswa tersebut sudah benar dalam 
mengambil titik yang akan diuji dan benar dalam pengoperasian matematikanya tetapi siswa tidak menuliskan kesimpulan atau jawaban dari soal tersebut, sedangkan dalam soal cerita program linier sangat penting untuk menyebutkan hasil yang diperoleh baik minimum maupun maksimum.

Penghasian max $\cdots$
$\begin{aligned}(0,10) & =200 \cdot 000(0)+100000(10) \\ & =1000 \cdot 000 \\ (4,8) & =200 \cdot 000(4)+100 \cdot 000(8) \\ & =800 \cdot 000+800 \cdot 000 \\ & =1 \cdot 600 \cdot 000 \rightarrow \text { upah.max. } \\ & =200 \cdot 000(7)+0 \\ & =1 \cdot 400 \cdot 000\end{aligned}$

(a)

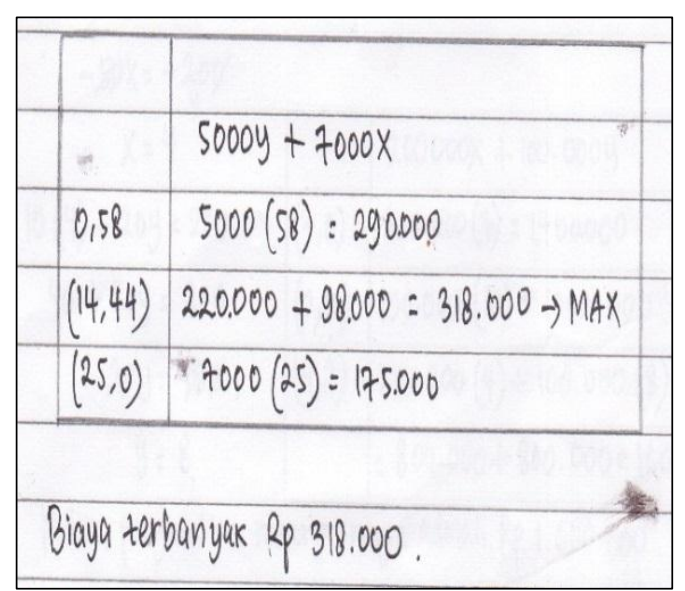

(b)

Gambar 12. Jawaban Lengkap dan Benar pada Pemahaman Operasi

Gambar 12 (a) dan (b) merupakan contoh jawaban siswa yang lengkap dan benar, karena pada jawaban siswa sudah memilih titik-titik yang tepat untuk diuji, sudah benar dalam pengoperasian matematikanya, dan siswa juga menuliskan kesimpulan berdasarkan yang ditanyakan dalam soal.

Dari hasil jawaban siswa dapat disimpulkan bahwa kemampuan pemahaman siswa pada operasi matematika terkait soal cerita program linier masih tergolong rendah dikarenakan seringnya terjadi kekeliruan saat menguji titik dan kesalahan yang dilakukan siswa saat mengoperasikan, serta kecerobohan tidak menuliskan kesimpulan.

Dari uraian di atas dapat disimpulkan bahwa kemampuan pemahaman siswa kelas XI dalam menyelesaikan soal cerita program linier terhadap 3 jenis kemampuan (konsep, prinsip, operasi) dapat dikategorikan cukup.

\section{SIMPULAN DAN SARAN}

Berdasarkan hasil penelitian dan pembahasan, dapat disimpulkan bahwa rata-rata kemampuan pemahaman siswa dalam menyelesaikan soal cerita materi program linier SMA Negeri 10 Palembang kelas XI dapat dikategorikan cukup dengan persentase sebesar 45,5\%. Dengan jenis indikator kemampuan pemahaman konsep diperoleh persentase sebesar 29\%, untuk indikator kemampuan pemahaman prinsip diperoleh persentase sebesar 53,8\%, dan untuk indikator kemampuan pemahaman prinsip diperoleh persentase sebesar 53,6\%.

\section{DAFTAR RUJUKAN}

Sanjaya, Wina. (2013). Penelitian Pendidikan. Jakarta: Kencana Prenada Media Group.

Seri, Herman. (2013). Buku Ajar Landasan Pendidikan. Palembang: Universitas Muhammadiyah Palembang. 